\title{
MIGRASI DALAM PERUBAHAN SOSIAL EKONOMI MASYARAKAT DESA TALANGO
}

\author{
Oleh : \\ Fajrin Nurul Qomariya ${ }^{1)}$, Hadi Soetarto ${ }^{2)}$, Nur Inna Alfiyah ${ }^{3)}$ \\ ${ }^{1)}$ Fakultas Ilmu Sosial dan Ilmu Politik Universitas Wiraraja Madura, ${ }^{2}$ Dosen Fakultas Ilmu \\ Sosial dan Ilmu Politik Universitas Wiraraja Madura, ${ }^{3)}$ Dosen Fakultas Ilmu Sosial dan Ilmu \\ Politik Universitas Wiraraja Madura \\ Email: fajrinnurulqomariya@ gmail.com ${ }^{1)}, \underline{\text { hadi18soetarto@ gmail.com }}^{2)}$ \\ Thebaddas7@gamil.com ${ }^{3)}$
}

\begin{abstract}
Population migration is an integral part of the development process in Indonesia. The phenomenon of migration that does not take place within a country is widely seen in various regions of Indonesia, each region certainly has different characteristics and each region has natural resources and human resources. which are not equal in number, this difference causes the distribution of the population to be uneven and also a change in mindset that is not in accordance with what is desired.

This study aims to describe an economic condition of the Talango village community caused by migration, which of course gives a good influence on an economic condition in terms of social and development in Talanago village.

The results of this study in the title Migration in Changes in Socio-Economic Conditions of the Talango Village Community, which describe several conclusions that have been studied and analyzed using the theory of Everett, S Lee 1970 in Purwanto, (2007: 2017) there are three factors that need to be considered in the process. population migration, among others, positive factors, negative factors, neutral factors discussion that can be taken from this research are as follows: positive factors where the population because someone wants to change their standard of living for the better, economic factors are the driving factors that people migrate to leave their place of residence development, the availability of jobs and opportunities to earn higher incomes are very accurate attractors in changing socio-economic conditions, and also higher opportunities to obtain education become attractive as migrant actors as students, favorable environmental conditions provide a pattern of life. up who live a prosperous life, and where progress at the destination is one of the most important accesses seen by migrant actors, while neutral factors are real factors that exist at the place of origin or destination are not yet the main factors, because in the end it returns to the response someone about these factors, personal sensitivity and intelligence, every time you make a decision from yourself there must be obstacles or obstacles there are a number of factors that keep people from staying there, and attract outsiders to move to that place, there are a number of negative factors that encourage people to move from the place.
\end{abstract}

Keywords: Migration, Driving Factors for Migration

\begin{abstract}
Abstrak
Migrasi penduduk merupakan bagian yang tidak terpisahkan dengan proses berkembangnya pembangunan di Indonesia fenomena migrasi yang tidak berlangsung dalam suatu negara banyak terlihat di berbagai wilayah Indonesia, setiap wilayah tentunya memiliki karakteristik yang berbeda-beda dan masing-masing wilayah memiliki sumber daya alam dan sumber daya manusia yang jumlahnya tak sama perbedaan inilah yang menyebabkan sebaran penduduk tidak merata dan juga suatu perubahan dalam pola pikir yang tidak sesuai dengan apa yang diinginkan.
\end{abstract}

79 | Jurnal Public Corner Fisip Universitas Wiraraja 
Dalam penilitian ini bertujuan untuk bagaimana mendeskripsikan suatu kondisi ekonomi masyarakat desa Talango yang disebabkan oleh dari migrasi, dimana hal ini tentunya meberikan penagruh yang baik terhadap suatu kondisi ekonomi dilihat dari segi sosial dan pembangunan yang ada di desa Talango.

Hasil penelitian ini dalam judul Migrasi dalam Perubahan Kondisi Sosial Ekonomi Masyarakat desa Talango, dimana memaparkan beberapa kesimpulan yang sudah dikaji dan di analisis menggunakan teori Everett, S Lee 1970 dalam Purwanto, (2007:2017) ada tiga yang menjadi faktor yang perlu diperhatikan dalam proses migrasi penduduk antara lain, faktor positif, faktor negatif, faktor netral pembahasan yang bisa diambil dari penelitian ini adalah sebagai berikut : faktor positif dimana penduduk karena seseorang ingin merubah taraf hidup menjadi lebih baik, faktor ekonomi merupakan faktor pendorong yang penduduk untuk bermigrasi meningalkan tempat tinggal mereka, tersedianya lapangan pekerjaan dan kesempatan memperoleh pendapatan yang lebih tinggi adalah penarik yang sanagt akurat dalam merubah siuatu kondisi sosial ekonomi, dan juga kesempatan yang lebih tinggi memperoleh pendidikan menjadi penarik sebagai pelaku migran sebagai pelajar, keadaan lingkungan yang menyenangkan memberikan pola hidup yang hidup yang sejahtera, dan dimana kemajuan di tempat tujuan menjadi salah satu akses terpenting yang dilihat oleh pelaku migran, sedangkan faktor netral merupakan faktor-faktor nyata yang terdapat di tempat asal atau tempat tujuan belum merupakan faktor utama, karena pada akhirnya kembali pada tanggapan seseorang tentang faktor tersebut, kepekaan pribadi dan kecerdasannnya, setiap memberikan keputusan dari diri sendiri pasti ada rintangan atau hambatan ada sejumlah faktor yang menahan orang untuk tetap tinggal di situ, dan menarik orang luar luar untuk pindah ke tempat tersebut, ada sejumlah faktor negatif yang mendorong orang untuk pindah dari tempat tersebut.

Kata Kunci : Migrasi, Faktor pendorong Melakukan Migrasi

\section{PENDAHULUAN}

Fenomena migrasi sangat mewarnai di beberapa negara berkembang, termasuk di berbagai daerah di Indonesia, terutama dalam konteks, banyak tenaga kerja yang berasal dari daerah pedesaan mengalir ke daerah perkotaan. Suatu desa merupakan hal yang relatif lamban dalam perubahan kondisi sosial-ekonomi dan setiap individu mempunyai kebutuhan yang berbeda, maka penilaian terhadap daerah asal dari masing-masing individu di masyarakat tersebut berbeda-beda, sehingga proses pengambilan keputusan untuk pindah dari masing-masing individu berbeda dalam pengembangan pedesaan tidak bisa dilepaskan dari kondisi sosial ekonomi masyarakat serta kemampuan masyarakat dalam mengakses sumber daya yang tersedia, dalam limitasi akses dan pemanfaatan sumber daya berakibat pada rendahnya kesempatan kerja pedesaan maka darihal ini untuk melakukan diversifikasi penghidupan yang salah satunya melalui migrasi. Menurut Purnomo (dalam Angga 2014 : 4 ) bahwa migrasi merupakan salah satu dinamika penduduk yang pada umumnya dipengaruhi oleh kebutuhan untuk mencari penghidupan yang layak, kelayakan tersebut dapat ditinjau dari perspektif ekonomi, fasilitas pendidikan, fasilitas kesehatan, kondisi sosial, budaya dan politik yang lebih baik dibandingkan 
dengan daerah asal.

Menurut Mulyadi (dalam Vina 2018 : 153) mengatakan bahwa migrasi penduduk desa ke kota adalah salah satu cara yang dilakukan masyarakat yang kondisi sosial ekonomi di daerah asal yang dianggap tidak memungkinkan untuk memenuhi kebutuhan mereka secara layak dimana pertumbuhan ekonomi di perkotaan yang lebih baik dari perdesaan dan terpusatnya diberbagai kegiatan ekonomi di perkotaan mendorong masyarakat untuk melakukan migrasi. Motivasi utama orang melakukan perpindahan ke perkotaan adalah suatu motif ekonomi, dimana adanya ketimpangan masalah ekonomi hal inimenjadi suatu kondisi yang pertimbangan rasional dimana individu melakukan mobilitas ke kota adalah adanya harapan untuk memperoleh pekerjaan dan memperoleh pendapatan yang lebih tinggi daripada yang diperoleh di desa.

Selain faktor ekonomi, faktor sosial dan budaya juga menjadi alasan yang tidak dapat dipisahkan dari bahan pertimbangan masyarakat melakukan migrasi. Salah satu daerah yang mencerminkan adanya fenomena migrasi antar daerah ( Inter Provincial migration) diperlihatkan oleh tenaga kerja asal Kabupeten Sumenep yaitu desa Talango. Talango merupakan suatu desa yang terletak di pulau poteran, pulau poteran meliki 8 desa yaitu desa Padike, Gapurana, Cabbiya, Essang, Palasa, Kombang dan Talango, dan talango mayoritas masyarakat disana adalah masyarakat yang bermigran kedaerah (Jakarta). Suatu masyarakat di desa talango kebanyakan masyarakat disana adalah seseorang yang berpindah tempat dari daerah satu kedaerah lain, hal ini menimbulkan suatu pengaruh bagi kelangsungan hidup bagi masyarakat di desa talango dimana dari hal ini tentunya para pelaku migran di desa talango memebrikan dampak bagi desanya sendiri entah itu memberikan dampak baik ataupun dampak buruk terhadap Desa Talango itu sendiri. Desa/Kelurahan dengan Jumlah kartu kelurga

$\begin{array}{ll}\text { Talango } & 2.079 \\ \text { Padike } & 1.811 \\ \text { Cabbiye } & 911 \\ \text { Essang } & 1.134 \\ \text { Kombang } & 992 \\ \text { Poteran } & 1.337 \\ \text { Palasa } & 1.430 \\ \text { Gapurana } & 2.895\end{array}$

Desa talango adalah suatu desa yang masyarakatnya adalah petani dan nelayan dan juga memanfaatkan suatu transportasi laut untuk dijadikan suatu transporatsi untuk menyebrang antara pelabuhan kalianget ke pulau talngo, dan masyarakat hanya bertumpu pada suatu 
pekerjaan tersebut yang mana juga tingkat pendidikan masih rata-rata dan hal ini yang menjadikan suatu masyarakat ingin bermigrasi terhadap suatu daerah yang terlihat lebih maju dan mampu memberikan ekonomi lebih baik, perubahan kondisi sosial ekonomi kehidupan yang semakin modern ini, menyebabkan seluruh masyarakat berlomba-lomba untuk berupaya untuk mensejahterakan kehidupannya, sehingga dapat memenuhi kebutuhan sehari-hari hal tersebut membuat masyarakat mencari berbagai peluang agar mendapatkan kehidupan yang lebih baik, peluang tersebut dimanfaatkan oleh masyarakat dengan sebaik- baiknya, sehingga peluang sekecil apapun akan masyarakat manfaatkan selama memberikan keuntungan. Tentang faktor-faktor yang mempengaruhi minat migrasi yang diduga mempengaruhi keputusan migrasi seperti usia, pendapatan, pekerjaan asal, tingkat pendidikan, status perkawinan, dan kepemilikan tanah juga faktor yang paling dominan mempengaruhi minat melakukan migrasi.

\section{TINJAUAN TEORITIS}

\subsection{Migrasi}

Migrasi penduduk merupakan bagian yang tidak terpisahkan dengan proses berkembangnya pembangunan di Indonesia fenomena migrasi yang berlangsung dalam suatu negara banyak terlihat di berbagai wilayah Indonesia. Dimana setiap wilayah di muka bumi tentunya memiliki karakteristik yang berbeda-beda dan masing-masing wilayah memiliki sumber daya alam dan sumber daya manusia yang jumlahnya tak sama perbedaan inilah yang menyebabkan sebaran penduduk di muka bumi tidak merata dan juga suatu perubahan dalam pola pikir yang tidak sesuai dengan apa yang diinginakan.

Mutua'li menjelaskan bahwa migrasi adalah perpindahan penduduk dengan tujuan untuk menetap dari suatu tempat ke tempat lain melampaui batas politik/negara ataupun batas administratif/batas bagian dalam suatu negara. Migrasi penduduk terjadi disebabkan adanya faktor pendorong dan faktor penarik masyarakat untuk bermigrasi ke daerah tujuan migrasi.

Menurut puspitasari (dalam Ihksan 2014:20) bahwa migrasi juga dapat diartikan sebagai perubahan tempat tinggal seseorang baik secara permanen maupun semi permanen, dan tidak ada batasan jarak bagi perubahan tempat tinggal tersebut. 
Proses migrasi internal dan internasional terjadi sebagai akibat dari berbagai perbedaan antara daerah asal dan daerah tujuan, perbedaan ini disebabkan oleh faktor ekonomi, sosial dan lingkungan, beberapa studi migrasi menyimpulkan bahwa migrasi terjadi disebabkan oleh alasan ekonomi, dan juga faktor ketertarikan sosial yang terjadi dengan alasan yaitu untuk memperoleh pekerjaan dan pendapatan yang lebih tinggi sehinga akan meningkatkan kualitas hidup.

Mantra 2008 (dalam Afdan 2015: 67) menyebutkan bahwa beberapa teori yang mengungkapkan mengapa orang melakukan migrasi, diantaranya adalah teori kebutuhan dan stres. Setiap individu mempunyai beberapa macam kebutuhan ekonomi, sosial, budaya, dan psikologis.Semakin besar kebutuhan tidak dapat terpenuhi, semakin besar stres yang dialami, apabila stres sudah melebihi batas, maka seseorang akan berpindah ke tempat lain yang mempunyai nilai kefaedahan terhadap pemenuhan kebutuhannya, perkembangan teori migrasi demikian dikenal dengan model stress-treshold atau placeutility.
(Sanis, 2010 : 30), menjelaskan teori migrasi menurut E.G Ravenstein dalam terdapat tujuh teori penggenerasian dari migrasi yakni, yang pertama migrasi dan jarak yang artinya banyak migran pada jarak yang dekat dan migran jarak jauh lebih tertuju ke pusatpusat perdagangan dan yang kedua adalah migrasi bertahap yang artinya adanya arus migrasi yang terarah dan adanya migrasi desa-kota, kota kecilkota besar, dan yang ketiga adalah suatu arus dan arus balik yang artinya setiap arus migrasi utama menimbulkan arus balik penggantiannya, dan yang keempat dimana adanya perbedaan desa dan kota mengenai kecenderungan melakukan migrasi, wanita melakukan migrasi pada jarak yang dekat dibandingkan pria, teknologi dan migrasi yang artinya bahwa teknologimenyebabkan migrasi meningkat, (g) motif ekonomi merupakan dorongan utama orang melakukan migrasi.

Menurut Michael P.Todaro (dalam Yustika, 2000:166) ketidak seimbangan desa dan kota dianalisa dari dua sudut, yaitu :

a. Dari sisi penawaran (supply), karena terjadi perpindahan 
penduduk terusmenerus maka akan terjadi arus urbanisasi yang berlebihan sehingga meningkatkan pertambahan penduduk perkotaan, yang pada akhirnya cenderung untuk menambah jumlah penawaran tenaga kerja di perkotaan. Sedangkan persediaan tenaga kerja di pedesaan semakin menipis.

b. Dari sisi permintaan (demand), disini penciptaan tenaga kerja di perkotaan lebih sulit dan mahal daripada penciptaan lapangan pekerjaan di pedesaan, karena adanya kebutuhan terhadap input- input komplementer yang sangat banyak

Menurut Mabogunje (dalam Mantra, 2000:184) menjelaskan bahwa hubungan migran dengan desa dapat dilihat dari materi informasi yang mengalir dari kota atau daerah tujuan ke desa asal. Informasi tersebut dapat berupa informasi positif atau negatif. Informasi yang positif biasanya dari para migran yang berhasil di daerah tujuan. Hal ini dapat berakibat :

a. Stimulus untuk pindah semakin kuat di kalangan migran potensial di desa. b. Pranata sosial yang mengontrol mengalirnya warga desa ke luar semakin longgar.

c. Arah pergerakan penduduk tertuju ke kota-kota atau daerah tertentu (tergantung dari mana datangnya informasi yang positif).

Munir

menjelaskan migrasi adalah perpindahan penduduk dengan tujuan menetap dari suatu tempat ke tempat lain melampaui batas politikatau batas bagian dalam suatu, migrasi sering diartikan sebagai perpindahan yang permanen dari suatu daerah ke daerah lain. Daerah yang lahan pertaniannya tandus umumnya masyarakatnya mencari pekerjaan ke daerah lain yang lebih subur atau banyak peluang ekonominya khususnya pada perdagangan, dan jasa. Dalam cakupan yang lebih luas, masyarakat atau tenaga kerja akan melakukan migrasi ke lain yang perekonomiannya lebih baik yang mampu menawarkan peluang kesempatan kerja dan peluang dengan penghasilan yang lebih baik.

Sebagaimana dikemukakan Munir (2013:137), dimana menjelaskan bahwa ada faktor menyebabkan bermigrasi 
(pushfactors) seperti:

a.Makin berkurangnya sumbersumber kehidupan, seperti menurunnya daya dukung lingkungan dan permintaan atas barang-barang tertentu

b. Menyempitnya lapangan pekerjaan di tempatasal

c. Adanya tekanan atau diskriminasi politik, agama, suku

d. Alasan pendidikan, pekerjaan atauperkawinan, dan

e. Bencana alam.

Sedangkan faktor-faktor penarik (pull factors) yang menyebabkan penduduk migrasi antara lain:

a. Harapan memperbaiki kehidupan

b. Kesempatan memperolehpendidikan yang lebih baik

c. Keadaan lingkungan dan keadaan hidup yang menyenangkan

d. Adanya aktivitas-aktivitas di kota besar, tempat-tempat hiburan atau pusat kebudayaan.

Dimana ada teori pengambilan keputusan bermigrasi di tingkat individu dari perspektif geografi yang berpengaruh kuat dalam analisis-analisis migrasi pada era 1970-an hingga menjelang awal tahun 1990 an, adalah teori yang diajukan oleh Everett S. Lee 1970, migrasi menurut Everett S.Lee (dalam Purwanto 2007 : 17) menjelaskan bahwa volume migrasi disuatu wilayah berkembang sesuai dengan tingkat keragaman daerahdaerah di wilayah tersebut.Pada daerah asal dan di daerah tujuan, menurut Lee, terdapat faktor-faktor yang disebut sebagai :

1. Faktor positif (+) yaitu faktor yang memberikan nilai keuntungan bila bertempat tinggal di tempat tersebut.

a. Kesempatan memperoleh pendapatan yang lebih tinggidibandingakan dengan daerah asal

b. Pendidikan yang lebih baik tempat tujuan dimana menjadi akses pendidikan yang tentunya lebib baik dari tempat asal

c. Taraf hidup yang lebih baik

d. Ketersedian akses transportasi dengan baik

e. Tersedianya lapangan pekerjaan yang lebih luas 
2. Faktor negatif (-) yaitu faktor yang memberikan nilai negatif atau merugikan bila tinggal di tempat tersebut sehingga seseorang merasa perlu untuk pindah ke tempatlain.

a. Pendapatan yang lebih rendah, hal ini terjadi di tempat asal sehingga perlu untuk memperbaiki pendapatanyang lebih baik

b. Ketersedianfasilitas transportasi menjadi hal yang paling penting dengan akses terlengkapi kebutuhan akan cepat tercapai

3. Faktor netral (0) yaitu yang tidak berpengaruh terhadap keinginan seorang individu untuk tetap tinggal di tempat asal atau pindah ke tempatlain. Perbedaan nilai kumulatif antara kedua tempat tersebut cenderung menimbulkan arus migrasi penduduk. Ketertarikan dari kesuksesan orang lain

a. Timbul dari diri sendiri

b. Tuntutan dari pola hidup

\subsection{Perubahan Sosial}

Perubahan sosial terjadi dengan siring waktu hal ini timbul dari lingkungan dan juga hasrat seseorang untuk melakukan perubahan, suatu kondisi sesorang merupakan tempat terjadinya suatu perubahan baik dalam perubahan sosial budaya ataupun ekonom.

Menurut Abdulsyani (dalam Reddy,2013:12) Kedudukan atau posisi seseorang dalam kelompok manusia yang ditentukan oleh jenis aktivitas ekonomi, pendapatan, tingkat pendidikan, usia, jenis rumah tinggal, dan kekayaan yang di miliki. Perubahan tersebut dapat berupa perubahan yang kecil sampai pada taraf perubahan yang sangat besar yang mampu memberikan pengaruh yang besar bagi aktifitas atau perilaku manusia. Perubahan sosial terjadi dalam setiap waktu dimana hal ini terjadi dari timbul hasrat seseorang untuk memalukan suatu perubaha yang terjadi dalam setiap keadaan, perubahan dapat mencakup aspek yang sempit maupun yang luas. Aspek yang sempit dapat meliputi aspek perilaku dan pola pikir individu.

"Aspek yang luas dapat berupa perubahan dalam tingkat struktur masyarakat yang nantinya dapat memengaruhi perkembangan masyarakat di masa yang akan datang. Secara berbeda dari waktukewaktu dari sebelum dan sesudah suatu aktivitas.dengan adanya aktivitas dan kegiatan maka akan menyebabkan perubahan sosial 
dengan meliputi berbagai bidangan ekonomi, pendidikan, teknologi, politik dan budaya" (Yusron Razak 2008: 180).

\subsection{Perubahan Kondisi Sosial}

\section{Ekonomi}

Mantra 2015 (dalam Lausiry 2018:12-14) bahwa sosial ekonomi adalah kedudukan atau posisi seseorang dalam kelompok manusia atau dalam ruang lingkup masyarakat yang ditentukan oleh jenis aktivitas social ekonomi, pendapatan, tingkat pendidikan, usia, jenis rumah tinggal, dan kekayaan yang dimiliki dan juga suatu pola hidup sesorang yang dilihat dari suatu kekuasan, membahas faktor sosial ekonomi, selalu berkaitan dengan beberapa hal yang berturutturut dan konsepsi. sebagai berikut :

1. Pendidikan

Menurut Kusnaedi dalam Purnomo 2013: pendidikan merupakan proses perkembangan pribadi, proses sosial, professional courses, serta seni untuk membuat dan memahami ilmu pengetahuan yang tersusun yang dikembangkan masa lampau oleh setiap generasi bangsa.

2. Status Sosial

Implikasi sosial menurut status dari Svalastoga (1989) adalah ukuran paling relevan dari perbedaan kelas atau status yang ditemukan di dalam pola interaksi suatu kelompok, karena kriteria interaksi adalah kriteria yang tepat dari status sosial.

3. Pendapatan

Pendapatan adalah imbalan yang diterima sebagai akibat dari penyerahan faktor produksi; yaitu tenaga kerja, modal tanah danentrepreneur. perkembangan ekonomi keluarga.Dalam keluarga, pendapatan dibagi menjadi 3 (tiga) kelompok; yaitu pendapatan rendah, sedang dan tinggi. Dalam perkembangan pembangunan, bagian pendapatan yang diterima kelompok berpendapatan tinggi lebih besar dari kelompok berpendapatan rendah sehingga terbentang jurang yang melebar antara kelompok berpendapatan tinggi dengan kelompok berpendapatan rendah (Sukirno, 2010).

4. Alokasi Pendapatan

Alokasi pendapatan menurut secara merata dalam suatu kebutuhan ekonomi keluarga diarahkan untuk mengurangi pemborosan dan dialihkan kepada upaya meningkatkan produktifitas sumber daya manusia dengan memperluas 
ruang gerak anggota keluarga agar dapat memberikan nilai tambahpada kegiatan ekonomi produktif.

Tidak ada masyarakat yang tidak mengalami perubahan, walaupun dalam taraf yang paling kecil sekalipun, masyarakat (individu) akan selalu berubah. Perubahan tersebut dapat berupa perubahan yang kecil sampai pada taraf perubahan yang sangat besar yang mampu memberikan pengaruh yang besar bagi aktifitas atau perilaku manusia, pada umumnya, faktor-faktor yang mempengaruhi perubahan sosial ekonomi dapat digolongkan pada faktor dari dalam dan faktor dari luar masyarakat. Tuntutan dan kebutuhan meenjadi landasan sebagai perubahan kondisi sosial ekonomi dan hal ini terjadi kepada masyarakat Talango, sebagai pelaku dari perubahan konsdisi, baik difaktor ekonomi maupun sosial, saat ini kita tau bahwa dimana menjadi seseorang yang terlihat bisa mengubah suatu kondisi sosial dan ekonominya, akan terlibat dalam era globalisasi.

\section{METODE PENELITIAN}

Metode yang digunakan dalam penelitian ini adalah kualitatif dengan jenis deskriptif. Kegiatan yang dilakukan peneliti dalam penelitian ini adalah mengumpulkan data yang erat hubungannya dengan proses dan tahapan dari suatu yang terjadi dalam perubahan sosial ekonomi yang terjadi di masyarakat Talango tentunya. Adapun pengertian metode penelitian kualitatif menurut Sugiyono (Sugiyono 2013) adalah sebagai berikut: Metode Kualitatif merupakan metode yang digunakan dalam meneliti pada kondisi obyek alamiah (sebagai lawannya adalah eksperimen) dimana peneliti adalah sebgai instrument kunci, tekhnik pengumpulan data dilakukan secara gabungan (tringulasi), analisis data bersifat induktif, dan hasil penelitian dan hasil penelitian kualitatif lebih menekankan makna dari pada generalisasi alasan pendekatan kualitatif dalam penelitian ini didasarkan pada dua alasan. Pertama, permasalahan yang dikaji dalam penelitian ini tentang migrasi dalam perubahan sosial ekonomi masyarakat desa Talango. Penelitian deskriptif adalah penelitian yang memberikan gambaran sistematis, tekstual dan akurat mengenai fakta-fakta dan sifat-sifat populasi atau daerah tertentu. Dimana dalam penelitian deskriptif dimaksudkan untuk memberikan gambaran tentang situasi, kegiatan atau peristiwa maupun fenomena tertentu. Keterangan untuk penelitian seperti ini dapat dikumpulkan bersumber dari hasil 
rekaman, wawancara, foto, dokumen, dan pengamatan langsung yang benar dilaporkan sesuai dengan makna yang sebenarnya data yang dikumpulkan dalam penelitian ini adalah berupa katakata,gambar, dan bukan angka-angka (Lexy J. Moleong, 2018: 20). Proses penelitian yang dilakukan dengan memperoleh hasil penjelasan yang mendalam mengenai suatu "Migrasi dalam Perubahan Sosial Ekonomi Masyarakat Desa Talango". Terkait dengan migrasi dimana menurut Everett, S Lee 1970 Everett S. Lee 1970, migrasi menurut Everett S.Lee dalam Purwanto, 2007 :17 menyatakan terdapat 3 faktor yang perlu diperhatikan dalam proses migrasi penduduk maka dari hal ini disebutkan:

i. Faktor positif (+) yaitu faktor yang memberikan nilai keuntungan bila bertempat tinggal di tempat tersebut.

1. Kesempatan memperoleh pendapatan yang lebih tinggi dibandingkan dengan daerah asal

2. Pendidikan yang lebih baik tempat tujuan dimana menjadi akses pendidikan yang tentunya lebib baik dari tempat asal

3. Taraf hidup yang lebih baik

4. Ketersedian akses transportasi dengan baik
5. Tersedianya lapangan pekerjaan yang lebih luas

ii. Faktor negatif (-) yaitu faktor yang memberikan nilai negatif atau merugikan bilatinggal di tempat tersebut sehingga seseorang merasa perlu untuk pindah ke tempatlain.

1. Pendapatan yang lebih rendah

Pendapatan yang lebih rendah, hal ini terjadi di tempat asal sehingga perlu untuk memperbaiki pendapatanyang lebih baik

2. Ketersedian fasilitas transportasi menjadi hal yang paling penting dengan akses terlengkapi kebutuhan akan cepat tercapai

3. Pendidikan

iii. Faktor netral (0) yaitu yang tidak berpengaruh terhadap keinginan seorang tetap tinggal di tempat asal atau pindah ke tempat lain. Perbedaan nilai kumulatif antara kedua tempat tersebut cenderung menimbulkan arus migrasi penduduk. Sebab terdapat daya tarik dan tawar pada masing- 
masing daerah khususnya daerah perkotaan.

1. Ketertarikan dari kesuksesan orang lain

2. Timbul dari diri sendiri

3. Tuntutan dari pola hidup

Informan yang dilibatkan merupakan orang yang dapat memberikan informasi tentang situasi dan kondisi, menguasai permasalahan secara mendalam, serta dapat dipercaya untuk menjadi sumber data, yang menjadi informan dalam penelitian ini yaitu :

1. Informan Kunci : Kepala Desa Talango bapak Adnan S.Sos

2. Informan Utama : Penduduk Desa Talango yang pernah melakukan Migrasi (ibu Imamalini, ibu Annisa Adatun, ibu Ida, ibu Marbua)

3. Informan Pendukung : Masyarakat Desa Talango yang belum pernah melakukan migrasi dan sebagai keluarga yang ditinggalkan (ibu Nira, ibu Yanti, ibu Topan ibu Sandiye)

\section{HASIL DAN PEMBAHASAN}

Pada bagian ini peneliti akan membahas data-data yang telah diperoleh melalui wawancara yang peneliti lakukan dengan informan,pembahasan ini menggunakan argument peneliti tentang suatu perubahan kondisi sosial ekonomi masyarakat desa Talango, disini peneliti menggunkan teori dari Everett, S Lee yaitu faktor positif, faktor negatif dan faktor netral.

\section{Faktor Positif}

$$
\text { Masyarakat desa Talango }
$$

bermigrasi dengan tujuan untuk merubah suatu keadaan yang menjadi tekanan ditempat asal maka ada beberpa yang menjadi penarik dari tempat tujuan yang mana menjadi peluang besar bagi msayarakat desa Talango, yang menjadi penarik ditempat tujuan atau kota adanya peluang kerja yang sangat luas dan juga hasil upah UMR yang sangat tinggi dibandingkan ditempat asal, dimana masyarakat desa Talango bermigrasi kekota yaitu kota seperti kota Surabaya dan juga kota Bali, masyarakat desa Talango membuka usaha dengan membuka warung sembako dan juga warung makanan da nada beberapa masyarakat desa Talango memeliki warung sembako sekitar 8 warung dengan penghasilan yang sangat banyak maka dari hal tersebut menjadi pengaruh sebagai penarik dari tempat tujuan yang mana memberikan suatu peluang usaha yang dengan memberikan penghasilan ekonomi yang sangat baik terhadap ekonomi masyarakat 
desa Talango, dan ada beberapa masyarakat desa Talango ketika berpualang ketampat asal membuka usaha seperti membuka warung sembako dan juga kosan didaearah Sumenep atau daerah asal hal ini menjadi hal positif dimana masyarakat memebrikan pengaruh terhadap kelangsungan ekonomi daerah asal dengan menambah perekonomian yang terdapat didarah asal.

Taraf hidup yang lebih baik menjadi penentu untuk melakukan migrasi, Masyarakat desa Talango hanya memiliki potensi dari sumber daya alam, dan juga masyarakat desa Talango hanya memliki pendidikan yang kebanyakan masih belum tamat sekolah dasar, sebagai lulusan hanya sekolah dasar lapangan peluang kerja atau usaha yang membuat tidak bisa meyakinkan untuk membuka usaha, dan hal ini juga berlaku di daerah manapun, dan lebih memilih untuk melakukan migrasi ke kota yang bisa memberikan kondisi ekonomi yang baik.

\section{Faktor Negatif}

Faktor pendorong dari dearah asal merupakan suatu keutamaan yang menjadi dasar untuk melaakukan migrasi seperti adanya kebutuhan yang harus terpenuhi maka masyarakat desa Talango berlombalomba untuk melakukan migrasi ke kota Jakarta dan Bali dan juga Surabaya dengan segala daya tarik yang dimiliki dikota tujuan dimana kota tujuan seperti Jakarta Surabaya dan juga bali dilihat merupakan suatu kota maju dalam industri, transportasi, infrastruktur dan pendidikannya merupakan salah satu hal penarik para pelaku migran sebagai pilihan destinasi mereka dalam upaya memperbaiki taraf kehidupan. Kota Jakarta dan Bali dan juga kota Suarabaya sebagai harapan pelaku migran di beberapa daerah di Indonesia dalam upaya memperbaiki taraf kehidupan, hingga sekarang masih menjadi daya tarik bagi masyarakat di luar Jakarta maka dari hal itu masyarakat melakukan migrasi untuk memperbaiki suatu kebutuhan taraf hidup yang lebih baik, masyarakat desa Talango juga mengatakan bahwa yang menjadi pendorong untuk melakukan migrasi karena melihat sanak family dan tetangganya sukses dikota tujuan, maka dari hal itu juga memberikan dorongan dengan merubah kondisi ekonominya, akan tetapi ada beberpa masyarakat desa Talango sudah melakukan migrasi tidak memiliki perubahan dalam ekonominya akan tetapi merubah suatu kondisi sosial yang bernilai negatif dimana ada beberapa masyarakat desa Talango mengalami pergaulan bebas dengan adanya migrasi hal ini terjadi rata-rata kepada anak muda yang juga ikut melakukan migrasi, tentunya hal tersebut menjadi faktor negatif terhadap kondisi sosial. 


\section{Faktor Netral}

Setiap individu memiliki kebutuhan yang perlu dipenuhi, kebutuhan tersebut dapat berupa kebutuhan ekonomi, sosial maupun psikologis, dan ketika suatu kebutuhan tidak terpenuhi maka akan terjadi pemikiran yang tidak tidak dan bisa dikatakan dengan stress. Ada dua yang dapat diakibatkan dari tekanan, apabila tekanan yang dirasakan oleh seorang individu masih dalam batas toleransi maka individu tidak akan pindah dengan tetap di daerah asal dan berusaha menyesuaikan kebutuhan dan fasilitas yang tersedia di lingkungan tersebut, namun apabila tekanan yang dirasakan oleh seorang individu di luar batas toleransinya maka individu tersebut akan mempertimbangkan untuk pindah ke tempat lain dimana dia merasa kebutuhankebutuhan yang diperlukan dapat terpenuhi dengan baik. Disetiap tempat asal ataupun tujuan, ada sejumlah faktor yang menahan orang untuk tetap tinggal di situ, dan juga menarik orang luar luar untuk pindah ke tempat tersebut, dan ada faktor negatif yang mendorong orang untuk pindah dari tempat tersebut, dan sejumlah faktor netral yang tidak menjadi masalah dalarn keputusan untuk migrasi. Selalu terdapat sejumlah rintangan yang dalam keadaan-keadaan tertentu tidak seberapa beratnya, tetapi dalam keadaan lain dapat diatasi,rintangan-rintangan itu antara lain adalah mengenai jarak, walaupun rintangan "jarak" ini meskipun selalu ada, tidak selalu menjadi faktor penghalang, rintangn-rintangan tersebut mempunyai pengaruh yang berbeda-beda pada orang-orang yang mau pindah, ada orang yang memandang rintanganrintangan tersebut sebagai hal sepele, tetapi ada juga yang memandang sebagai hal yang berat yang menghalangi orang untuk pindah. Pertumbuhan ekonomi mampu membawa pengaruh positif bagi kesempatan kerja dan produktivitas tenaga kerja, penduduk desa Talango mengatakan bahwa pendapatan dapat menyebabkan seseorang untuk melakukan perpindahan, dimana rendahnya pendapatan di daerah asal dan pengharapan yang besar untuk memperoleh pendapatan yang lebih baik di daerah tujuan merupakan faktor paling dominan yang mempengaruhi seseorang dalam bermigrasi.

\section{PENUTUP}

- Kesimpulan

Faktor Positif

Penduduk di desa Talango bermigrasi dengan adanya peanrik dari tempat tujuan yang mana dari hasil wawancara masyarakat desa Talango ingin merubah suatu ekonomi, dan juga dimana kesempatan bekerja ditempat tujuan seperti ibu kota Jakarta dan Bali memebrikan suatu perubahan yang bisa dikatakan merubah dalam hal ekonomi dan 
perubahan pada pola gaya kehidupan, hal ini bisa dibuktikan banyaknya kendaraan beroda empat dan rumah-rumah yang bagus di didesa Talango, maka penarik dari tujuan pastinya memberikan pengaruh positif dalam kehidupan pelaku migran.

Faktor Negatif

Pendorong dari seseorang untuk melakukan migrasi adalah masalah ekonomi dimana hal ini juga terjadi di desa Talango, masyarakat talango mengatakan dari hasil wawancara bahwa yang menjadi pendorong adalah keinginan dalam memperoleh ekonomi yang lebih baik dan juga memiliki pekerjaan yang lebih baik, dimana masyarakat desa talango mata pencaharian lebih kepada buruh tani dan juga bertani, maka dari hal ini yang menjadi dasar untuk merubah suatu ekonominya

Faktor Netral

Sedangkan faktor netral merupakan faktor-faktor nyata yang terdapat di tempat asal atau tempat tujuan belum merupakan faktor utama, karena pada akhirnya kembali pada tanggapan seseorang tentang faktor tersebut, kepekaan pribadi dan kecerdasannnya. Dimana setiap memberikan keputusan dari diri sendiri pasti ada rintangan atau hambatan ada sejumlah faktor yang menahan orang untuk tetap tinggal di situ, dan menarik orang luar luar untuk pindah ke tempat tersebut, ada sejumlah faktor negatif yang mendorong orang untuk pindah dari tempat tersebut, dan sejumlah faktor netral yang tidak menjadi masalah dalarn keputusan untuk migrasi. Selalu terdapat sejumlah rintangan yang dalam keadaanKeadaan tertentu tidak seberapa beratnya, tetapi dalam keadaan lain dapat diatasi.

- Saran

- Faktor positif (+) yaitu faktor yang memberikan nilai keuntungan bila bertempattinggal di tempat tersebut, dimana ketika berada ditempat tujuan dimana saran yang diberikan terhadap pemerintah kota:

- Memberikan lahan yang bisa menjadikan bisa membuka usaha, variabel masyarakat saat ini migrasi menjadi salah satu tujuan utama mendapatkan akses yang baik ditempat tujuan seperti yang sudah peneliti akatakan kepemilikan tanah berpengaruh secara signifikan terhadap minat migrasi, memberikan lahan yang bisa digunakan untuk pembangunan fasilitas kegiatan perindustrian yang dan 
juga tidak merusak lingkungan.

- Memberikan target perizinan yang ketat untuk melakukan migrasi dan agar tidak penumpukan penduduk atau kepadatan penduduk di kota tempat migrasi.

- Faktor negatif (-) yaitu faktor yang memberikan nilai negatif ataumerugikan bilatinggal di tempat tersebut sehingga seseorang merasa perlu untuk pindah ke tempatlain. Maka dari hal ini perlu dengan campur tangan masyarakat bagaimana masyarakat bisa bertempat tinggal dengan nyaman di tempat asal, seperti halnya :

- Pemerintah daerah supaya bisa menciptakan lapangan pekerjaan dan memberikan

keterampilan di daerah pedesaan khususnya (di Desa Talango), memberi pinjaman modal untuk membuka usaha industri- industri kecil sehingga mampu mengurangi pelaku mobilitas atau migrasi untuk tidak meninggalkan daerahnya dan untuk meningkatkan pendapatan masyarakat melalui usaha tersebut.

- Pemerintah

mengembangkan potensi di berbagai daerah supaya kesejahteraan masyarakat juga dapat meningkat, karena hampir semua responden mengatakan bahwa faktor pendapatan di daerah asal lebih rendah dibandingkan dengan daerah tujuan membuat mereka berpikir untuk bekerja di luar daerah dengan harapan mendapat pendapatan yang lebih baik.

- Faktor netral (0) yaitu yang tidak berpengaruh terhadap keinginan seorangindividu untuk tetap tinggal di tempat asal atau pindah ke tempat lain.Perbedaan nilai kumulatif antara kedua tempat tersebut cenderung menimbulkan arus 


$$
\begin{aligned}
& \text { migrasi penduduk sebab } \\
& \text { terdapat daya tarik dan tawar } \\
& \text { pada masing-masing daerah } \\
& \text { khususnya } \\
& \text { daerahperkotaan,maka saran } \\
& \text { yang diberikan adalah }
\end{aligned}
$$

- Mempunyai skil terlebih dahulu, dan juga memiliki pengalaman yang baik dan percaya diri yang baik, untuk memulai pekerjaan.

- Pemerintah memberikan pelatihan khusus terhadap masyarakat yang nantinya mempunyai planning untuk mealukan migrasi agar ketika melakukan migrasi baik antar Negara antar kota masyarakat tidak canggung untuk mencari pekerjaan dan juga hal ini juga bias mengurangangi pengangguran baik di kota asal dan kota tujuan.

\section{DAFTAR PUSTAKA}

\section{Buku}

Ahmad, Jamaluddin. 2015. Metode Penelitian Administrasi Publik: Teori dan Aplikasi. Yogyakarta:
Gava Media.

Lauer, H, Robert. 1993. Perspectif On Social Change. ( Tentang Perubahan Sosial). Jakarta: PT Rineka Cipta

Lutfi Muta'ali. 2015. tekknik Analisis Regional. Badan Penerbit FakultasGeogafi (BPFG). Universitas Gadjah Mada. Yogyakarta.

Moleong, Lexy J. 2018. Metode Penelitian Kualitatif. Bandung: Remaja Rosdakarya Offset.

Munir, Rozy. 2010. Sensus Penduduk. 2010. Dasar-dasar Demografi. Jakarta Selatan. Selemba Empat

Mantra, Ida Bagus. 2013. Demografi Umum. Pustaka Pelajar. Yogyakarta.

P. Siagian,Sondang. 2000. Adminitrasi Pembangunan. Jakarta. PT Bumi Aksara

Razak, Yusron. 2008. Sosiologi Sebuah PengantarTinjauan Pemikiran Sosiologi Perpesktif Islam.Laboratorium Sosilogi Agama

Santoso,Iman M. 2012. Perspektif Imigrasi dalam Migrasi Manusia. Jakarta. Pustaka Reka Cipta Sugiyono. 2014. Metode Penelitian Kombinasi Mixed Methods(Pendekatan Kuantitatif, 
Kualitatif, dan R\&D). Bandung.

Alfabeta

S, Mulyadi. 2003. Ekonomi Sumber Daya

Manusia. Jakarta: PTRajagrafindo

Persada, Yustika, Erani. 2000.

Industrialisasi Pinggiran.

Yogyakarta : Pustaka Pelajar.

Jurnal

Iksan Wali Muhammad. 2014. Analisis Migrasi Kota Banda Aceh.Jurnal Ekonomi dan Kebijakan Publik. 01.(1), 2442-7411. Diunduh pada tanggal 25 November 2020.

Mahfiro Adila, 2015. Arahan Pengembangan Desa Talango sebagai Desa Puast Pertumbuhan di Pulau Poteran Kecamatan Talango, Kabupaten Sumenep.Skripsi Perencanaan Wilayah dan Kota. RP141501. Diunduh 1 mei 2021

Niari Refda dkk,2012. Faktor-Faktor Pendorong dan Penarik yang Menyebabkan Penduduk Suku Banten Bermigrasike Kelurahan 